\title{
Ambient air monitoring of nitrogen dioxide at Kalimati, Tirtomartani, Kalasan, Sleman, Yogyakarta
}

\author{
Supriyanto $^{l,}$ and Indah Suci Ramadhani ${ }^{2}$ \\ ${ }^{1}$ Environmental Engineering Department, Faculty of Civil Engineering and Planning, Universitas Islam Indonesia , J1. Kaliurang 14,5 \\ Yogyakarta 55584 \\ ${ }^{2}$ Study Program of Environmental Engineering, Faculty of Civil Engineering and Planning, Universitas Islam Indonesia , Jl. \\ Kaliurang 14,5 Yogyakarta 55584
}

\begin{abstract}
Nitrogen dioxide $\left(\mathrm{NO}_{2}\right)$ is one of parameters in air quality according to Indonesia Government No. 41/1999. $\mathrm{NO}_{2}$ has influence in respiratory problem of human being if it exceeds threshold level (400 $\mathrm{gNO}_{2} / \mathrm{Nm}^{3}$ ). This study is air monitoring of $\mathrm{NO}_{2}$ concentration in ambient air and it uses a Griess Saltzman method using the spectrophotometer (Indonesia Standard SNI 19-7119.2-2005) near of Plywood Industry and Main Road. The sampling location has two points at Kalimati Village, Tirtomartani, Kalasan, Sleman, D.I Yogyakarta. On December 2016, the results show which $\mathrm{NO}_{2}$ concentration is below threshold level with $0,469 \mu \mathrm{g} \mathrm{NO} / \mathrm{Nm}^{3}$ at first point and $0,234 \mu \mathrm{g} \mathrm{NO} / \mathrm{Nm}^{3}$ at second point.
\end{abstract}

Keywords: Ambient Air Monitoring, Nitrogen Oxide, Kalimati, Griess-Saltzzman

\section{Introduction}

Nitrogen Oxide $\left(\mathrm{NO}_{2}\right)$ is outdoor air pollutant [1] and it causes environmental problem such as health problem in respiratory problem and acid rain[2]-[4]. $\mathrm{NO}_{2}$ come from combustion process with use oxygen excess [3]. $\mathrm{NO}_{2}$ is also come from reaction between Nitric Oxide, $\mathrm{NO}$ and Oxygen, $\mathrm{O}_{2}$ in internal combustion engine. Therefore, $\mathrm{NO}_{2}$ is resulted from transportation sector both gasoline engine and diesel engine. This study objective is to monitor ambient air near Stack of Plywood industry at Kalimati Village, Purwomartani, Kalasan, Yogyakarta (LS 744’26.67' BT 110²7'45.47') and Main Road.

\section{Methodology}

\subsection{Sampling Location}

The air monitoring used two sample locations. The first sample location has agreement with the wind direction and the north of industrial plywood stack [5]. Table 1 shows the coordinate sampling point and table 2 presents the sampling scheduling on December 2016

Table 1. Coordinate of Sampling Location

\begin{tabular}{|c|c|}
\hline Location & Coordinate Point \\
\hline \multirow{2}{*}{ First } & LS 7 $44^{\prime} 25.7028^{\prime \prime} \mathrm{BT}$ \\
& $110^{\circ} 27^{\prime} 50.6016^{\prime \prime}$ \\
\hline \multirow{2}{*}{ Second } & $\begin{array}{c}\text { LS } 7^{\circ} 44^{\prime} 20.598^{\prime \prime} \mathrm{BT} \\
110^{\circ} 27^{\prime} 47.1456^{\prime \prime}\end{array}$ \\
\hline
\end{tabular}

Table 2. Sampling Shcedule

\begin{tabular}{|c|c|}
\hline Day & Time \\
\hline Monday/Tuesday Afternoon & $13.00-14.00$ \\
\hline Thusday Morning & $09.00-10.00$ \\
\hline
\end{tabular}

\subsection{Sampling and Analysis}

$\mathrm{NO}_{2}$ sampling used single impinger with flow rate $0.4 \mathrm{lpm}$ (liter per minute) and NO2 analysis used Griess-Saltzman Method with spectrophotometer $550 \mathrm{~nm}$. The analysis concept is NO2 absorb by solution Griess-Saltzman to form azo-dye substance with pink in 15 minute [6].

\section{Result and Discussion}

\subsection{Sampling Location}

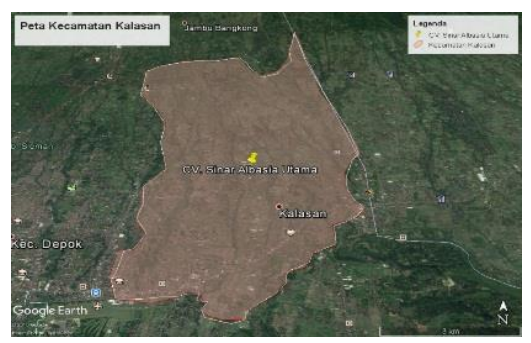

Fig. 1. Map of Kalasan, Sleman, Yogyakarta 


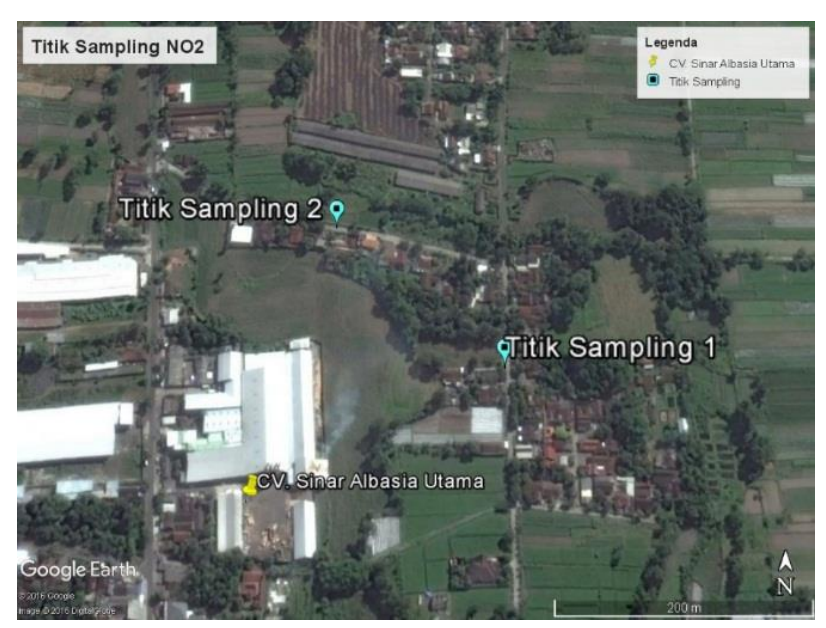

Fig. 2. Map of Sampling Location

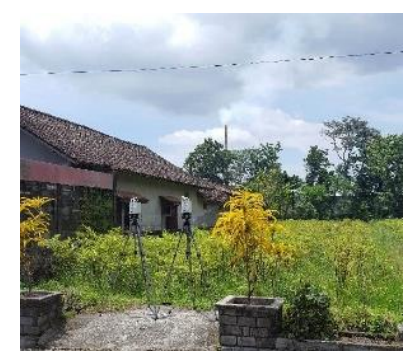

(a)

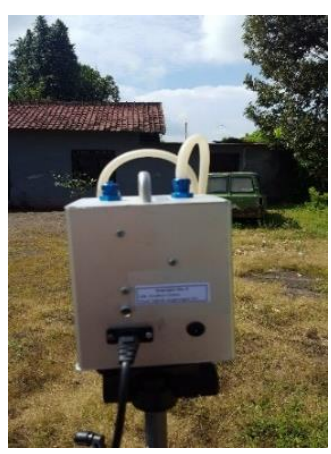

(b)
Fig. 3. Sampling location at first point (a) and second point (b)

\subsection{Sampling and Analysis}

$\mathrm{NO}_{2}$ sampling used single impinger with flow rate $0.4 \mathrm{lpm}$ (liter per minute) and $\mathrm{NO}_{2}$ analysis used Griess-Saltzman Method with spectrophotometer $550 \mathrm{~nm}$. The analysis concept is NO2 absorb by solution Griess-Saltzman to form azo-dye substance with pink in 15 minute.

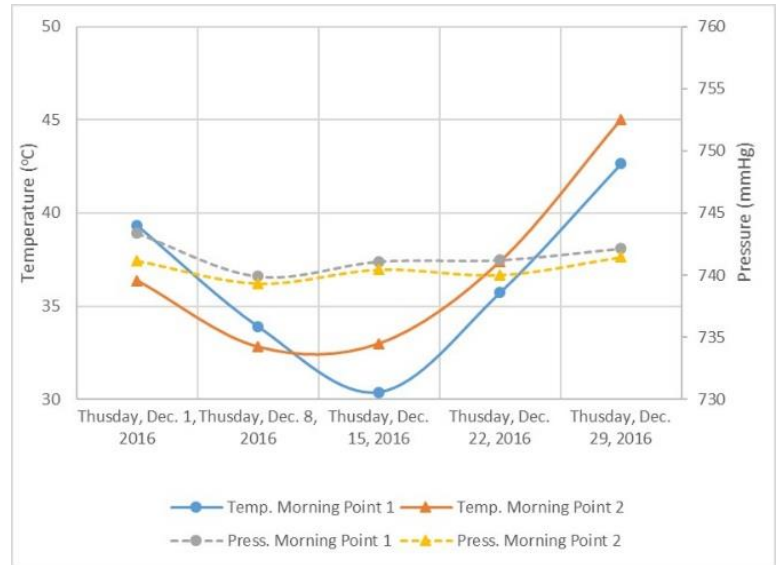

Fig. 4. Temperature and Pressure for Morning Day

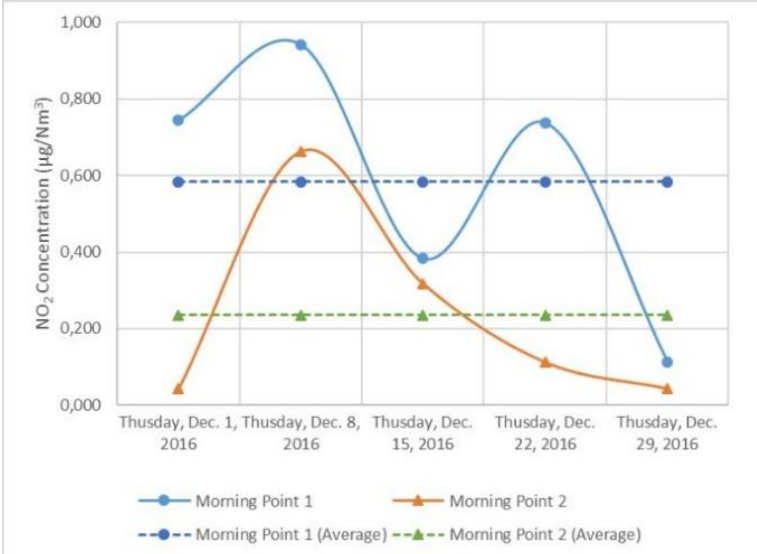

Fig. 5. $\mathrm{NO}_{2}$ Concentration for Morning Day

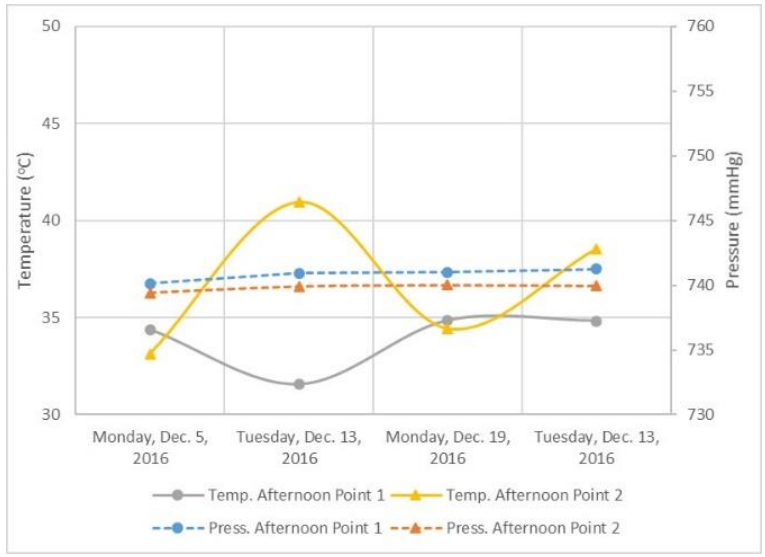

Fig. 6. Temperature and Pressure for Afternoon Day

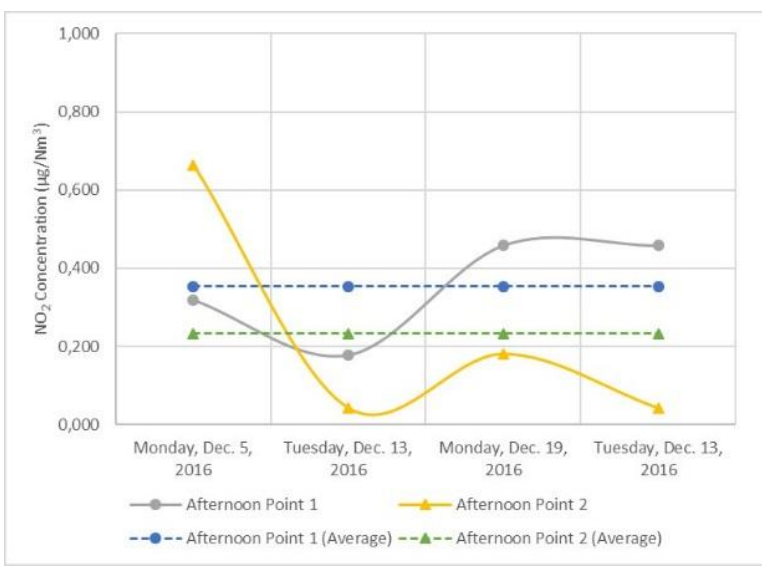

Fig. 7. $\mathrm{NO}_{2}$ Concentration for Afternoon Day

At the first point in figure 4 Morning temperature is between $30-45^{\circ} \mathrm{C}$, Pressure is around $740 \mathrm{mmHg}, \mathrm{NO}_{2}$ concentration is slightly below $0.600 \mu \mathrm{g} / \mathrm{Nm} 3$ in average. During afternoon in figure 6 , the temperature between 32 to $42^{\circ} \mathrm{C}$, Pressure is around $740 \mathrm{mmHg}$. $\mathrm{NO}_{2}$ concentration is slightly above $0.35 \mu \mathrm{g} / \mathrm{Nm}^{3}$. Temperature has influence during ambient air monitoring [6]. Temperature from morning to afternoon $37 \mathrm{oC}$ in average, and the reduce concentration two times. At the second point in figure 5, Morning temperature is between 30- 
$45^{\circ} \mathrm{C}$, Pressure is around $740 \mathrm{mmHg}$. $\mathrm{NO}_{2}$ concentration is slightly below $0.600 \mu \mathrm{g} / \mathrm{Nm}^{3}$ in average. During afternoon, the temperature between 32 to $42^{\circ} \mathrm{C}$, Pressure is around $740 \mathrm{mmHg}$. Figure 7 shows which $\mathrm{NO}_{2}$ concentration is somewhat above $0.35 \mu \mathrm{g} / \mathrm{Nm}^{3}$. So temperature from morning to afternoon $37^{\circ} \mathrm{C}$ in average, and the reduce concentration two times.

\section{Conclusions}

The ambient air monitoring has conducted at Kalimati Village, Tirtomartani, Kalasan, Sleman, Yogyakarta. On December 2016. Sampling location of $\mathrm{NO}_{2}$ used two points and analysis of $\mathrm{NO}_{2}$ used Griess-Saltzman method. The results show which $\mathrm{NO}_{2}$ concentration is below threshold level with $0,469 \mu \mathrm{g} \mathrm{NO} / \mathrm{Nm}^{3}$ at first point and $0,234 \mu \mathrm{g} \mathrm{NO}_{2} / \mathrm{Nm}^{3}$ at second point.

Authors thanks to Environmental Engineering Department, Universitas Islam Indonesia for Research and Conference Grant

\section{Reference}

1. G. Hoek et al., "Satellite NO2 data improve national land use regression models for ambient NO2 in a small densely populated country," Atmos. Environ., vol. 105, pp. 173-180, 2015.

2. H. J. Lee and P. Koutrakis, "Daily ambient NO2 concentration predictions using satellite ozone monitoring instrument $\mathrm{NO} 2$ data and land use regression," Environ. Sci. Technol., vol. 48, no. 4, pp. 2305-2311, 2014.

3. L. N. Lamsal, R. V. Martin, D. D. Parrish, and N. A. Krotkov, "Scaling relationship for NO2 pollution and urban population size: A satellite perspective," Environ. Sci. Technol., vol. 47, no. 14, pp. 78557861, 2013.

4. United States Environmental Protection Agency, "Basic Information About NO2," Nitrogen Dioxide (NO2) Pollution, 2016. [Online]. Available: https://www.epa.gov/no2-pollution/basicinformation-about-no2\#What is $\mathrm{NO} 2$.

5. S. R. A. Rahman, S. N. S. Ismail, M. F. Ramli, M. T. Latif, E. Z. Abidin, and S. M. Praveena, "The Assessment of Ambient Air Pollution Trend in Klang Valley, Malaysia," World Environ., vol. 5, no. 1, pp. 1-11, 2015.

6. Badan Standarisasi Nasional. SNI 7119-2.2005. Udara ambien - Bagian 2: Cara uji kadar nitrogen dioksida $\left(\mathrm{NO}_{2}\right)$ dengan metode Griess Saltzman menggunakan spektrofotometer, 2005. 